\title{
Inhibition effect of calcium hydroxide point and chlorhexidine point on root canal bacteria of necrosis teeth
}

\author{
Andry Leonard Je*, Achmad Sudirman** and Karlina Samadi ** \\ * Dental Practician \\ ** Department of Conservative Dentistry \\ Faculty of Dentistry Airlangga University \\ Surabaya - Indonesia
}

\begin{abstract}
Calcium Hydroxide point and Chlorhexidine point are new drugs for eliminating bacteria in the root canal. The points slowly and controly realease Calcium Hydroxide and Chlorhexidine into root canal. The purpose of the study was to determined the effectivity of Calcium hydroxide point (Calcium hydroxide plus point) and Chlorhexidine point in eleminating the root canal bacteria of nescrosis teeth. In this study 14 subjects were divided into 2 groups. The first group was treated with Calcium hydroxide point and the second was treated with Chlorhexidine poin. The bacteriological sampling were measured with spectrofotometry. The Paired T Test analysis (before and after) showed significant difference between the first and second group. The Independent T Test which analysed the effectivity of both groups had not showed significant difference. Although there was no significant difference in statistical test, the result of second group eliminate more bacteria than the first group. The present finding indicated that the use of Chlorhexidine point was better than Calcium hydroxide point in seven days period. The conclusion is Chlorhexidine point and Calcium hydroxide point as root canal medicament effectively eliminate root canal bacteria of necrosis teeth.
\end{abstract}

Key words: Calcium hydroxide plus point, Chlorhexidine point, necrosis teeth

Correspondence: Andry Leonard Je, c/o: Dental Practician. Jln Praban No. 10 Surabaya.

\section{INTRODUCTION}

The diseases of the pulp tissue and periapical lesion are caused by pathogen bacteria infection. The main bacteria causing the infection have not yet been known. It has been said that infection in the root canal is infection of polimicroba. ${ }^{1}$ If the pulp tissue infected, the root canal treatment should be done. Root canal treatment could be done by taking all the infected pulp tissue in the pulp chamber and the root canal. ${ }^{2}$ The treatment will show a good result if the whole infected pulp tissue has taken out by root canal preparation, appropriate sterilization has been done, and the root canal has been filled appropriately. ${ }^{1}$

The use of medicament for sterilization in root canal treatment plays an important role, since the elimination of bacteria and its substrate is the main factor of a success root canal treatment. The bacteria elimination could be achieved by chemo-mechanical preparation and the use of antibacterial medicament.

Brystrom and Sundqvist ${ }^{3}$ showed that there are proliferation of the remaining bacteria in the root canal after the chemomechanical preparation. It is an established procedure to use calcium hydroxide $\left[\mathrm{Ca}(\mathrm{OH})_{2}\right]$ as a therapeutic component to achieve sterilization of infected root canals. Studies has been conducted for a long time to examine the antibacterial effect of Calcium hydroxide and chlorhexidine on root canal microorganism. ${ }^{3}$ Calcium hydroxide was initially introduced as pulp capping material by Hermann in 1930 and since then its use in the field of endodontic has been increasing. Now the use of calcium hydroxide is one of recommended material for root canal sterilization. ${ }^{4}$ Calcium hydroxide is effective for root canal treatment since it could fill whole pulp chamber and the hydroxide ion diffuse through dentine tubulus and root canal ramification entering the area of bacteria and its product. Calcium hydroxide could prevent re-infection by disturbing the supply of bacteria nutrition, since its $\mathrm{pH}$ affects the cell membrane and protein structure of bacteria. ${ }^{5}$

Another root canal medication is chlorhexidine, a cationic material with wide spectrum antibacterial. The characteristic of cationic material is it makes easier contact with anion on the surface of bacteria and changes its integrity. Potassium ion is the first substance which can been seen when the sitoplasma membrane is damaged. The change of the permeability of sitoplasma membrane could cause precipitation of sitoplasma protein, changed of the osmotic cell balance, disturbing growth metabolism, splitting cells, blocking the ATP membrane, and prevent anaerobic process. ${ }^{6}$

Now gutta percha which contain root canal medication is invented. Five percent chlorhexidine diasetat material is added into solid gutta percha as chlorhexidine point. One of its brand is Active Point produced by Roeko, which is available in sizes $15-80$. The chlorhexidine point releases the diasetat chlorhexidine slowly from gutta percha matrix. The surface of gutta percha matrix releases much 
chlorhexidine, while the inside of gutta percha releases chlorhexidine slower. The affinity of chlorhexidine on dentin makes its concentration remain stable for some times. Calcium hydroxide point also has been produced by Roeko (Calcium hydroxide plus point), which contain 52\% calcium hydroxide, $42 \%$ gutta percha, sodium chloride surfactant, and coloring agent. These two materials are used for root canal medications. The benefits of these materials are no mixing procedure, easy to apply, left no residue, and the root canal could be filled from periapical to coronal.

The purpose of the study was to examined the inhibition effect of the calcium hydroxide point and Chlorhexidine point on root canal bacteria. The clinician could choose the best root canal medication by knowing the ability of the calcium hydroxide point and the Chlorhexidine point in eliminating root canal bacteria.

\section{MATERIALS AND METHODS}

The maxillary anterior teeth from patients aged 18-45 years who visited Airlangga University Dental Hospital, were choose as the samples. The teeth were diagnosed as pulp necrosis due to dental caries with no periapical lesion, and had straight single root canal.

The informed consent from the patients were taken prior to the study. The samples were divided into 2 groups, group one used Calcium hydroxide point material (1 piece), and group two used Chlorhexidine point material (1 piece). Each group consisted of 7 samples.

Aseptic procedures were done to all the tools, materials, and teeth before the treatment. The teeth were isolated using rubber dam and the cavity entrance was made using a high speed bur. After that the necrotic pulp tissue was taken by extirpation needle. Files needle no 10 was inserted to pulp chamber until $1 \mathrm{~mm}$ prior root apex, and diagnostic wire photo was taken to measure the work length of root canal preparation.

The tooth was preparated using file type $\mathrm{K}$ with conventional technique. Each time changing the file number, the irrigation was carried out using $30 \%$ of $\mathrm{H}_{2} \mathrm{O}_{2}$ (2.5 cc) and aquabidest $(2.5 \mathrm{cc})$ with light pressure. The root preparation was continued until file no. 70 . Each file type K no. 10-70 was used only for 3 teeth samples. After root preparation finished, the root canal was dried up using 6 pieces sterile paper points. A new sterile paper point inserted into the root canal and kept it for one minute. Then, it was put into the culture media Brain Heart Infusion (BHI) broth and incubated in $37^{\circ} \mathrm{C}$ for 24 hours, and the bacteria number was counted using spectrofotometri. The root canal was sterilized using a point of Calcium hydroxide no. 60 . The remaining points were cut with excavator $2 \mathrm{~mm}$ prior the orifice, covered by cotton pellet and temporary filling. The patients were recalled 7 days later.

At the recalled visit (7 days later), the patients were checked whether the temporary fillings still good. The teeth were isolated using rubber dam and temporary filling were opened. The root canal medications were taken out, followed by irrigation of $3 \% \mathrm{H}_{2} \mathrm{O}_{2}$ and aquabidest of $2.5 \mathrm{cc}$ with light pressure. Then it were dried up with 6 pieces sterile paper point. Another a new sterile paper point was put into the root canal and kept for one minute. Then it was put into the culture media BHI broth and incubated in $37{ }^{\circ} \mathrm{C}$ for 24 hours. The bacteria counting were done using spectrofotometri. The teeth were sterilized again by putting the root canal medications, covered by cotton pellet and temporary filling.

Reaction tube containing sterile BHI broth was placed inside spectrophotometry, and wave length was arranged at $600 \mathrm{~nm}$ and calibrated to 0 . The BHI broth which contained 24 hours incubated bacterial breeding was shaked until homogenous for 3 minutes with Vibrax stirring tool. Afterwards, it was moved to another reaction tube without paper point, placed again inside the spectrophotometry, so that the bacterial density value was shown with digital numbers. The higher the result, the more bacteria in the BHI broth.

Data was analyzed with Paired T Test before and after treatment, and Independent $\mathrm{T}$ Test for Calcium Hydroxide point and Chlorhexidine point.

\section{RESULTS}

Table 1 showed that after treatment with Calcium hydroxide point and Chlorhexidine point, the number of bacteria decreased. Acquired data was homogeneous, normal, tested with One Sample Kolmogorov-Smirnov Test. To analyze the difference between before and after treatment with Calcium hydroxide point and Chlorhexidine point, Paired T Test was used with $\mathrm{p}<0.05$. This analysis showed a significant difference between before and after treatment with Calcium hydroxide point and Chlorhexidine point. To determine the difference of two materials, Independent $\mathrm{T}$ Test was utilized. Table 2 showed no significant difference between the breeding result of Calcium hydroxide point and Chlorhexidine point.

Table 1. The mean, standard deviation and Paired $\mathrm{T}$ Test on the turbidity value of the bacteria before and after giving Calcium hydroxide point and chlorhexidine point

\begin{tabular}{lcccc}
\hline \multirow{2}{*}{ Group } & $\mathrm{N}$ & \multicolumn{2}{c}{$\overline{\mathrm{X}} \pm \mathrm{SD}$} & $\mathrm{p}$ \\
\cline { 3 - 4 } & & Before & After & 0.001 \\
\hline Calcium hydroxide point & 7 & $0.745 \pm 0.071$ & $0.303 \pm 0.033$ & 0.001 \\
Chlorhexidine point & 7 & $0.795 \pm 0.079$ & $0.196 \pm 0.018$ & \\
\hline
\end{tabular}


Tabel 2. The result of statistical test using Independent T Test the difference of the turbidity value of the bacteria before and after between the group of hydroxide Calcium point and chlorhexidine point

\begin{tabular}{cccc}
\hline Group & $\begin{array}{c}\text { Clorhexidine } \\
\text { point }\end{array}$ & $\begin{array}{c}\text { Calcium } \\
\text { hydroxide point }\end{array}$ & $\mathrm{p}$ \\
\hline$\overline{\mathrm{X}} \pm \mathrm{SD}$ & $0.599 \pm 0.069$ & $0.442 \pm 0.045$ & 0.081 \\
\hline
\end{tabular}

\section{DISCUSSION}

From statistical Paired T Test result, the bacterial turbidity value before and after treatment with Calcium hydroxide point and Chlorhexidine point showed a significant difference $(\mathrm{p}<0.05)$. This finding proved that both Calcium hydroxide point and Chlorhexidine point had antibacterial effect. Treatment with both substances could reduce bacterial count inside root canal which previously had been biomechanically prepared. From bacterial count, a difference of bacterial turbidity value before and after Calcium hydroxide point treatment was $0.442 \pm 0.045$, while the difference in Chlorhexidine point treatment was $0.599 \pm 0.069$. The Independent $\mathrm{T}$ Test had shown that there was no significant difference for the difference of bacterial turbidity value between Calcium hydroxide point and Chlorhexidine point ( $\mathrm{p}=0.081$ which was more than 0.05). Although there was no significant difference between two substances, Chlorhexidine point eliminated more bacteria than Calcium hydroxide.

The ability to eliminate more bacteria was possibly caused by Chlorhexidine point as a strong kation, interacted with negative content bacterial cell wall influencing tissue osmotic pressure, causing contraction of cell membrane and later died. Chlorhexidine effect entered bacterial cytoplasma causing precipitation of cytoplasma content so that mitochondria did not produce energy anymore, lysis, disturbing glycolytic enzyme which eventually decreasing acid production, and then bacteria died. In low concentration it was bacteriastatic, and in high concentration it gave bactericidal effect. In gutta percha form, it was a slow released device (SRD) which possessed high ability to enter dentinal tubuli in relatively short time to give maximal antibacterial effect until $500 \mu \mathrm{m}$, and in dentinal tubuli bacteria were not found. ${ }^{7}$ Chlorhexidine was capable to inhibit the growth of Enterococcus faecalis, capable to penetrate the biofilm layer produced by Enterococcus faecalis colony. ${ }^{8}$

Gutta percha had a basic substance which enabled it to be used as root canal sterilization medicine containing Chlorhexidine, it possessed ISO standard measurement and radio-opaque in nature. Soon after root canal preparation and irrigation was done, gutta percha was inserted into root canal. Drying root canal was not necessary since gutta percha could still release Chlorhexidine in wet condition. ${ }^{7}$

Accurate point application matching with work length was crucial to give antibacterial effect along root canal and avoiding excessive substance get to periradicular tissue. Taking out gutta percha after 7 days application was easy, no remnats on root canal wall (as in paste form), which later on could disturb the bonding of root canal filling material. ${ }^{7}$

A study by Lin et al..$^{9}$ demonstrated Chlorhexidine had a better antibacterial effect compared to Calcium hydroxide. Gomes et al. ${ }^{10}$ stated that although Calcium hydroxide had antibacterial effect, in his research Calcium hydroxide could not kill and eradicate Enterococcus faecalis at any given time, meanwhile, Chlorhexidine in $2 \%$ gel form, was able to perform antibacterial activities towards Enterococcus faecalis after 1,2,7, and 15 days.

Many researchers affirmed that Chlorhexidine was significantly better towards Enterococcus faecalis and Candida albicans compared to Calcium hydroxide. But not all researches agreed with the statement above as Lyne et al. ${ }^{8}$ wrote that both Chlorhexidine and Calcium hydroxide were equally effective.

Hydroxide ions released from Calcium hydroxide had the ability to enter into teeth tissue and have affinity with dentin, direct contact with bacteria inside dentinal tubuli. On the other hand, ions inside gutta percha, released, and formed interaction inside root canal, so that the concentration increased to eliminate root canal bacteria. One mechanism to explain antibacterial activity of Calcium hydroxide was the absorption of carbondioxide $\left(\mathrm{CO}_{2}\right)$ inside root canal, where the gas was essential for bacteria. If Calcium hydroxide absorbed carbondioxide, then $\mathrm{CO}_{2}-$ depending - bacteria could not endure living. ${ }^{10}$

It could be concluded from this research that the application of Chlorhexidine point into root canal was able to eliminate bacteria growth more than the application of Calcium hydroxide point even after root canal preparation. Although from statistical test there was no significant difference between both medications, Chlorhexidine point and Calcium hydroxide point are good materials, both are applicable for root canal sterilization due to easy application and effective antibacterial effect supporting root canal treatment. Further research to examine more detail the effect of both materials should be done.

\section{REFERENCES}

1. Walton RE, Torabinajed M. Prinsip dan praktek ilmu endodonsi. Edisi ke-2. Jakarta: Penerbit Buku Kedokteran EGC; 1998. p. 360-78.

2. Cohen C, Burn RC. Pathways of the pulp. $8^{\text {th }}$ ed. St Louis: Mosby; 2002. p. 231-91.

3. Podbielksi A, Spahr A, Haller B. Additive antimicrobial activity of Calcium Hydroxide and Chlorhexidine on common endodontic bacterial pathogen. J Endod 2003 May; 29(5):340-5.

4. Evans MD, Baumgartner C, Khemaleelakul S, Xia T. Efficacy of Calsium hydroxide: chlorhexidine paste as an intracanal medication in bovine dentin. J Endod 2003 May; 29(5):338-9.

5. Spangberg LSW. Intracanal medication. In: Ingle JI, Bakland L, editors. Endodontics. $4^{\text {th }}$ ed. Baltimore: Williams \& Wilkins; 1994. p. $627-40$. 
6. Wuerch RMW, Apicella MJ, Mines P, Yancich PJ, Pashley DH. Effect of $2 \%$ chlorhexidine gel as an intracanal medication on the apical seal of the root canal system. J Endod 2004 Nov; 30(11): 788-91.

7. Lin S, Zuckerman O, Weiss EI, Mazor Y, Fuss Z. Antibacterial efficacy of a new chlorhexidine slow release device to desinfect dentinal tubules. J Endod 2003 Jun; 29(6):416-8

8. Suzuki K. Antimicrobial effect of Calcium Hydroxide on bacteria isolated from infected root canals. Dentistry in Japan 1999; 35:43-7.
9. Lin Y, Mickel AK, Chogle S. Effectiveness of selected materials againts Enterococcus faecalis: Part 3. The antibacterial effect of Calcium Hydroxide and Chlorhexidine on Enterococcus faecalis. J Endod 2003 Sep; 29(9):565-6.

10. Gomes BP, Souza SF, Ferraz CC, Teixeira FB, Zaia AA, Valdrighi L, Souza-Filho FJ. Effectiveness of 2\% Chlorhexidine gel and Calcium Hydroxide against Enterococcus faecalis in bovine root dentine in vitro. Int Endod J 2003 Apr; 36(4):267-75. 